\title{
Transcriptional alteration of genes linked to gastritis concerning Helicobacter pylori infection status and its virulence factors
}

Seyedeh Zohre Mirbagheri

Tehran University of Medical Sciences

Ronak Bakhtiari

Tehran University of Medical Sciences

Hashem Fakhre Yaseri

Iran University of Medical Sciences

Abbas Rahimi Foroushani

Tehran University of Medical Sciences

Seyyed Saeed Eshraghi

Tehran University of Medical Sciences

Masoud Alebouyeh ( $\square$ masoud.alebouyeh@gmail.com )

Shahid Beheshti University of Medical Sciences School of Medicine https://orcid.org/0000-0001-74742515

\section{Research Article}

Keywords: Helicobacter pylori, Gastritis. Inflammation, virulence genotype, NF-KB pathway

Posted Date: May 14th, 2021

DOl: https://doi.org/10.21203/rs.3.rs-484619/v1

License: (c) (1) This work is licensed under a Creative Commons Attribution 4.0 International License. Read Full License 


\section{Abstract}

\section{Background}

Helicobacter pylori infection and heterogeneity in its pathogenesis could describe diversity in the expression of inflammatory genes in the gastric tissue. We aimed to investigate transcriptional alteration of genes linked to gastritis concerning the $H$. pylori infection status and its virulence factors.

\section{Methods and Results}

Biopsy samples of 12 infected and 12 non-infected patients with $H$. pylori that showed moderate chronic gastritis were selected for transcriptional analysis. Genotyping of H. pylori strains was done using PCR and relative expression of inflammatory genes was compared between the infected and non-infected patients using relative quantitative real-time PCR. Positive correlations between transcriptional changes of IL8 with TNF- $a$ and Noxo1 in the infected and TNF- $a$ with Noxo1, MMP7, and Atp4A in the non-infected patients were detected. Six distinct genotypes of $H$. pylori were detected that showed no correlation with gender, ethnicity, age, endoscopic findings, and transcriptional levels of host genes. Irrespective of the characterized genotypes, our results showed overexpression of TNF-a, MMP7, Noxo1, and ATP4A in the infected and $I L-8$, Noxo1, and ATP4A in the non-infected patients.

\section{Conclusions}

A complexity in transcription of genes respective to the characterized $H$. pylori genotypes in the infected patients was detected in our study. The observed difference in co-regulation of genes linked to gastritis in the infected and non-infected patients proposed involvement of different regulatory pathways in the inflammation of the gastric tissue in the studied groups.

\section{Introduction}

Gastritis is a common disease among humans in different populations. Although this disease can control by therapeutic regimens, its chronic form could lead to cancer. Gastritis is a multifactorial and complex disease associated with both the environment, such as lifestyle, eating habits, and infections and genetic factors (1). Helicobacter pylori (H. pylori), which is known as the first carcinogenic bacteria, can cause gastritis and chronic inflammation through different mechanisms, including histopathological changes of the gastric tissue that are mediated by its virulence factors, induction of the immune system leading to the infiltration of neutrophils and lymphocytes as well as the production of proinflammatory cytokines, production of substances, such as ammonia, phospholipases, and cytotoxins, which lead to increased risk of malignant alterations of the gastric stem cells $(1,2)$. The infection occurs during infancy and may remain silent for decades in the gastric environment throughout life. The infection and pathophysiological abnormalities of chronic gastritis (CG) could lead to the loss of functional glands (atrophy) and replacement of the normal gland and foveolar epithelium with intestinal-type cells, intestinal metaplasia, and progress to dysplasia, and carcinoma (3). H. pylori also can cause other 
diseases, such as peptic and duodenal ulcers, mucosa-associated lymphoid tissue lymphoma, or other conditions, such as recurrent aphthous stomatitis, anemia, altered serum levels of lipoproteins, and coronary atherosclerosis in some patients (3-7).

Different virulence factors are attributed to $H$. pylori that are linked to gastric disorders. Cytotoxicassociated gene $A(\operatorname{Cag} A)$, vaculotating cytotoxin $A(\operatorname{Vac} A)$, and several other virulence factors such as outer membrane proteins (OMPs), are involved in $\mathrm{H}$. pylori-induced gastric inflammation via the activation of gene transcription $(1,8)$. Interaction of these virulence factors with host cell receptors on gastric epithelial cells has been described in both in vitro and in vivo studies (1). These interactions trigger intracellular signaling events that result in the release of proinflammatory cytokines and promote bacterial evasion from the acidic environment of the stomach, local mechanical stress, and native immune response $(2,4)$. Although infiltration of plasma cells, neutrophils, monocytes, differentiation of the gastric cells to the intestinal type cells, and depletion of the parietal cells in the gastric tissue are among common histological changes occurring following the infection, no congruency exist to link some of these virulence factors with these changes (8).

Many research works have been carried out to find gene expression profiles of gastric cancer in tumor tissues; however, there are very few studies that provide information about gene expression analysis in pre-cancerous tissue, especially in patients with chronic gastritis, and its link with different genotypes of H. pylori virulence factors. The induction of nuclear factor $\mathrm{kB} /$ tumor necrosis factor-alpha (NF-kB/TNF-a) inflammatory pathway is known to be the major route of immune-dependent carcinogenesis in the stomach (9). Activation of NF-KB by H. pylori induces nuclear translocation, which causes an increase in transcription of NF-KB responsive genes, like interleukin (IL)-8, and up or down-regulation of inflammatory genes (2). In this pathway, TNF-a, IL-8, nicotinamide dinucleotide phosphate (NADPH) oxidase 1 (NOXO1), Matrix metallopeptidase 7 (MMP-7), and ATPase H+/K+ Transporting Subunit Alpha (ATP4A) cooperate to promote inflammation and histological changes in the gastric tissue (10-12).

Heterogeneity in the pathogenicity of the infection among patients seems to depend on the genotype of H. pylori strains carrying different virulence factors, and the extent of induction of genes mediating the activation of this pathway. Understanding this correlation possibly could illustrate observed diversity in the severity of the inflammation and its progress toward cancer. In this study, to describe this relationship, changes in transcription levels of key genes of the NF- $k B$ inflammatory pathway, including $T N F-a, I L-8$, Nox01, Atp4aA, and MMP-7 were explored and their link with common virulence genotypes of related isolates was analyzed on gastric biopsy samples of patients with gastric disorders.

\section{Materials And Methods}

\section{Patients and samples}

The study was performed on outpatients who were referred to the endoscopic ward of a general hospital in Tehran, Iran from January to August of 2019. This study was approved by the ethical committee of the Research Center in Tehran University of Medical Science (accepted Number, IR.TUMS.SPH.REC.1398.167 
$1398 / 7 / 3$ ) and an informed consent form was obtained from all the patients. Demographic and clinical information of patients recorded in a questionnaire form. Patients who had received non-steroidal antiinflammatory drugs or antibiotics within the last six weeks were excluded from this study. Three biopsy specimens of patients with gastric complaints were obtained during endoscopy from the antrum (the distal region of the stomach), and were used for histological examination, H. pylori culture and rapid urease test, and RNA extraction.

\section{Histological examination}

Biopsy specimens in the pathology department were histologically examined by hematoxylin-eosin staining method and the grade of gastritis was described based on histological parameters and updated Sydney System. Patients samples with chronic gastritis were selected for further analysis.

\section{Isolation and identification}

Each biopsy specimen for culture were kept in a transport medium consisting of thioglycollate with 1.3 $\mathrm{g} / \mathrm{L}$ Agar (Merck, Germany) with 3\% yeast extract (Oxoid, UK) and were transferred to the laboratory in less than 2 hours, then were homogenized and cultured on Brucella Agar supplemented with 7\% sheep blood, Campylobacter selective supplement (vancomycin $2.0 \mathrm{mg}$, polymyxin $0.05 \mathrm{mg}$, trimethoprim 1.0 $\mathrm{mg}), 10 \%$ fetal calf serum, and amphotericin B $(2.5 \mathrm{mg} / \mathrm{L})$. Incubation was performed in microaerophilic conditions at $37^{\circ} \mathrm{C}$ for 5-7 days. Identification of $\mathrm{H}$. pylori isolates was performed by analyzing colony morphology, Gram staining, positive reactions of oxidase and catalase, and urease activities.

Confirmation of the identity was done using specific primers for $\mathrm{H}$. pylori $(\mathrm{g} / \mathrm{mM})$ by polymerase chain reaction (PCR) as described before (13). The isolates were preserved in $\mathrm{BHI}$ broth containing $20 \%$ glycerol and $10 \%$ fetal calf serum and stored at $-70^{\circ} \mathrm{C}$.

\section{Genotyping of $H$. pylori isolates}

\section{DNA extraction}

Genomic DNA of harvested colonies was extracted as described by Douraghi M (14). Briefly, harvested colonies of the $H$. pylori isolates were suspended in $1 \mathrm{ml} \mathrm{PBS}$. After centrifugation (6,000 rpm, $5 \mathrm{~min})$, the pellets were resuspended in $50 \mathrm{mM} / \mathrm{L} \mathrm{NaOH}$ and heated at $100^{\circ} \mathrm{C}$ for 20 minutes. After a quick spin and addition of $1 \mathrm{M}$ Tris- $\mathrm{HCl}, \mathrm{pH} 7.5$, centrifuged for $5 \mathrm{~min}$ at 3,000 rpm. The supernatants containing genomic DNA samples were stored at $-20^{\circ} \mathrm{C}$ until used for molecular studies.

\section{Genotyping}

ollowed by a 10 -min incuba-

tion in $1 \mathrm{~mol} / \mathrm{L}$ Tris $/ \mathrm{HCl}(\mathrm{pH} 7.5)$

ollowed by a $10-$ min incuba- 
tion in $1 \mathrm{~mol} / \mathrm{L}$ Tris / $\mathrm{HCl}(\mathrm{pH} 7.5)$

In this study, genotyping of the isolates was done by PCR. Primers for detection of $\operatorname{cagA}, \operatorname{cag} L, c a g Y$, $\operatorname{vac} A$ (s and $\mathrm{m}$ alleles), and ice $A 1$ and ice $A 2$ genes were used in separate reactions as described before $(13,15,16)$. Each genotype was defined according to a distinct pattern of the virulence genes detected as follows, $\operatorname{cag}^{+/-} / \operatorname{cagL}^{+/-} / \operatorname{cag}^{+/-} / \operatorname{vac} A\left(\mathrm{~s}_{1 / 2} / \mathrm{m}_{1 / 2}\right) / \mathrm{ice} \mathrm{A} 1^{+/-} / A 2^{+/-}$.

\section{Gene expression analysis}

\section{RNA extraction and cDNA synthesis}

To analyze the extent of alteration in the transcription of inflammatory genes in patients with chronic gastritis, RNA extraction of the gastric biopsy samples was done using TRIzol reagent (BlueZol, Iran) following the manufacturer's guidelines with some modifications. Briefly, the tissue samples were cut into small pieces and mixed thoroughly with $600 \mu$ l of the extraction solution (BlueZol, Iran). After the addition of $150 \mu \mathrm{l}$ chloroform and vigorous vortex for 15 seconds, the resulting mixture was centrifuged at 12000 rpm for $15 \mathrm{~min}$ at $4^{\circ} \mathrm{C}$. The colorless upper aqueous phase was transferred to a new clean tube and mixed with $400 \mu \mathrm{l}$ of isopropanol. The mixture was frozen at $-70{ }^{\circ} \mathrm{C}$ for 30 minutes, and the obtained RNA pellet $\left(12,000 \mathrm{rpm}, 15 \mathrm{~min}\right.$ at $\left.4^{\circ} \mathrm{C}\right)$ was mixed with $1 \mathrm{ml} 80 \%$ ethanol. A gentle vortex was applied to suspended the white plate at the bottom of the microtube. The extracted RNA in the pellet of the mixture was obtained after centrifuged at $7500 \mathrm{rpm}$ for $5 \mathrm{~min}$ at $4^{\circ} \mathrm{C}$. Each pellet was resuspended in 20-30 $\mu \mathrm{l}$ DEPC treated water, and stored at $-70^{\circ} \mathrm{C}$ after heat treatment in $60^{\circ} \mathrm{C}$ for 5 minutes. The extracted RNA concentration was measured by quantitative method (Nano Drop ${ }^{\text {TM }}$ One Microvolume UV-Vis

Spectrophotometers). cDNA synthesis was done after adjustment of RNA concentrations using the easy cDNA synthesis kit (Parstous, Iran), according to the manufacturer's instruction.

\section{Detection of primer efficiency}

The efficiency of primers targeting TNF- $a, I L-8$, Noxo1, MMP-7, Atp4A, B2M, and ACTB genes was measured before each analysis. The nucleotide sequence of these primers is shown in Table 1.

\section{Relative quantitative real-time PCR}

The expression level of IL-8, TNF-a, Noxo1, MMP-7, ATP4A genes in the H. pylori-infected compared with $H$. pylori non-infected patients with chronic gastritis was measured using SYBR green quantitative realtime PCR. B2M and ACTB genes were used as endogenous genes as described before (17). The reaction mixture consisted of $0.5 \mu \mathrm{L}$ of each primer, $12.5 \mu \mathrm{L}$ RealQ Plus Master Mix Green (Ampliqon, Denmark), 2 $\mu \mathrm{L}$ of cDNA, and distilled water up to the final volume of $25 \mu \mathrm{L}$. The thermal cycling conditions in Rotor Gene 6000 Corbett Sequence Detection System have comprised an initial denaturation step at $95^{\circ} \mathrm{C}$ for 10 min, 40 cycles of denaturation at $95^{\circ} \mathrm{C}$ for 30 seconds, annealing at $60^{\circ} \mathrm{C}$ for 60 seconds, elongation at $72{ }^{\circ} \mathrm{C}$ for 60 seconds, and a final extension step at $72{ }^{\circ} \mathrm{C}$ for $3 \mathrm{~min}$. All the reactions were tested in duplicate. To show the accuracy of the amplification for each gene, primer efficiency, melting curve 
analysis, and gel electrophoresis were done. Relative gene expressions for all samples were determined

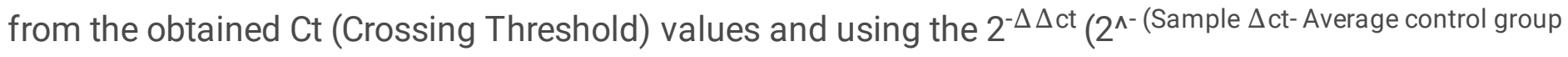
$\Delta c t)$ method. Up- and down-regulation were defined based on RQ values $\geq 2$ and $\leq 0.5$, respectively (18).

\section{Statistical analysis}

Statistical analyses and graphical representation of results were performed using SPSS ( 25 version) and GraphPad Prism7 softwares. The correlation between the relative expression values of $I L-8, T N F-$ a, Noxo1, MMP-7, ATP4A genes in the infected group was evaluated by Spearman's correlation nonparametric test. As well, the correlation between $H$. pylori genotypes and relative expression values of these genes in the $H$. pylori-infected patients with chronic gastritis was evaluated by Kruskal-Wallis nonparametric test. $p$-value $\leq 0.05$ was considered statistically significant.

\section{Results}

\section{Phenotypic and histological results}

A total of 168 volunteer patients with gastric disorders (Male, 41.1\% and Female, 58.9\%), and a mean age of 46 years ranging from 17-86 years, were included in this study. H. pylori infection was detected in $27.4 \%(46 / 168)$ of the biopsy specimens. Histopathologic analysis showed that $87.5 \%(147 / 168)$ had chronic gastritis, where $41.49 \%$ (61/147) of them presented moderate chronic gastritis in their histological tests. Atrophy, metaplasia, and dysplasia were not detected in these samples. Among the patients with moderate chronic gastritis, biopsy samples of the $H$. pylori-infected and non-infected patients were selected for further analysis. Demographic and pathological information for the patients is presented in supplementary (Table 1). All of the H. pylori isolates in the infected patients showed positive results for common biochemical, enzymatic, and PCR ( $g / m M$ gene) tests.

\section{Characteristics of $H$. pylori genotypes}

Genotypic characteristics of $H$. pylori isolates showed six distinct genotypes (supplementary, Table 1). Statistical analysis showed no correlation between these genotypes and gender, ethnicity, age, and endoscopic findings.

\section{Expression and correlation of IL-8, TNF-a, MMP7, Noxo1and ATP4A genes in two groups of patients}

The efficiency of primers targeting TNF- $a, I L-8$, Noxo1, MMP-7, Atp4A genes was between 0 and 1 . Alteration in transcriptional levels of key inflammatory and carcinogenic genes was measured in the gastric tissue samples. The relative expression levels (mean $\pm S D$ ) of these genes revealed are presented in Table 2. Accordingly, overexpression of TNF-a,MMP7, Noxo1and ATP4A genes in the infected group and $I L-8$, Noxo1, and ATP4A genes in the non-infected group was detected (Figure 1). Given that the distribution of data was not normal, Spearman's correlation nonparametric test was used to compare coregulation of different genes linked to the inflammatory pathway in $H$. pylori-positive and -negative 
groups. There were positive correlations between the expression of TNF- $a$ and $I L-8$ genes $(r=0.636, P$ $=0.026), T N F-a$ and Noxo1 genes $(r=0.573, P=0.05), l L-8$ and Noxo1 genes $(r=0.601, P=0.039)$ in $H$. pylori-positive group and positive correlations between the expression of TNF- $a$ and MMP-7 genes $(\mathrm{r}=0.657, P=0.020)$, TNF- $a$ and Noxo1 genes $(\mathrm{r}=0.629, P=0.028), T N F-a$ and ATP4A genes $(\mathrm{r}=0.573, P$ $=0.051)$ in $H$. pylori-negative group that were statistically significant.

\section{Comparison between $H$. pylori genotypes and relative expression values of genes}

As was shown in Figure 1, relative expression levels of $I L-8, T N F$ a, MMP7, Noxo1, and ATP4A genes in $H$. pylori-infected patients with defined genotypes were compared. Statistical analysis doesn't show a correlation between genotypes and the extent of expression for each gene. A link between $H$. pylori genotype A (cagAt/vacA s1 $1 \mathrm{~m} 1$ ) and increased levels of expression for $I L-8, T N F-a$, and MMP-7 was shown, which were inversely accompanied with the lower level of Noxo1 and ATP4A expression compared with the other genotypes. The lowest level of changes in the transcription of the studied genes compared with the non-infected patients was detected in a patient infected with $\mathrm{H}$. pylori genotype $\mathrm{F}$ (cagA-/vacA s2m2). Patients infected with genotype A and C showed the highest level of MMP7 and TNF$a$ expression compared with other genotypes (1.87 and 3.35-fold $v s 0.77 \pm 0.34$ and 2.52 and 2.55 -fold vs $0.47 \pm 0.28$, respectively). While expression of $I L-8, T N F-a$, and $M M P-7$ was higher in biopsy of patients infected with genotype A strains, the expression of ATP4A and Noxo 1 genes was higher in the patients infected with a more related genotype (genotype B, 16.91 and 3.76 folds, respectively). The patients infected with genotype $\mathrm{C}$ of $\mathrm{H}$. pylori presented the highest transcription level of TNF-a, MMP-7, and Noxo1 genes $(2.55,3.35$ and 1.69 folds, respectively) compared to other genotypes $(0.88 \pm 0.94$, $0.96 \pm 0.51$, and $0.62 \pm 0.52)$.

\section{Discussion}

Gastritis is a common disease among humans in different populations. This is estimated that more than half of the world population experience chronic gastritis in different degree and extent. The role of chronic gastritis as a serious and insidious illness in the path of gastric carcinogenesis remains largely unknown. H. pylori infection is one of the most important contributors of gastritis that shows great diversity in its genomic content in different geographic locations $(1,15)$.

Host inflammatory responses are mediated through several mechanisms, including induction of oxidative-reductive stress response pathway, activation of cytotoxic immune cells, B cell activation, and permanent secretion of inflammatory cytokines and chemokines (2). Although real mechanisms of gastritis and its progression toward gastric cancer after $H$. pylori infection are poorly known, in vitro studies showed that induction of the nuclear factor-kB (NF-kB) inflammatory pathway is a critical regulator in this relationship. Activation of this pathway could promote immune-dependent inflammation and histological changes in the stomach (9).

A total of 1840 genomics types of $H$. pylori have been described according to the GenBank database, which shows great diversity in this bacterium that is due to its impaired DNA repair system and 
evolutionary events. Pathogenicity of this bacterium in strains with intact type 4 secretion system is commonly linked to the expression of CagA, VacA, IceA, Urease, together with adhesions and outer membrane proteins. Finding a link between the genotypes of this bacterium and the extent of inflammatory response in the gastric tissue is hard, since there are several variants of each virulence gene. In this study, our results confirmed this complexity in the studied patients.

Results of our study showed a complexity between the extent of transcription in genes related to inflammation and gastric carcinogenesis and genotypes of the H. pylori isolates. Nearly half of the patients were infected with wild-type genes, while the absence of some virulence genes was detected in other samples. Totally, six different genotypes of $H$. pylori were detected in biopsy samples of patients with $C G$, which represented similar diversity as were reported from previous studies in Iran (15). Genotype A $\left(\mathrm{Cag} \mathrm{A}^{+} / \mathrm{Cag} \mathrm{Y}^{+} / \mathrm{Cag} \mathrm{L}^{+} / \mathrm{Vac} \mathrm{A} m_{1} s_{1} /\right.$ ice $\left.\mathrm{A1}^{+}\right)$, which seems to present the highest pathogenicity based on in vitro studies, was detected in $25 \%$ of the patients. Histological analysis in the patients infected with this genotype showed similar pathogenicity compared with the patients infected with genotype $\mathrm{C}$, a genotype with low virulence capacity ( $\mathrm{Cag} \mathrm{A}^{-} / \mathrm{Cag} \mathrm{Y}^{-} / \mathrm{Cag} \mathrm{L}^{-} / \mathrm{Vac} \mathrm{Am}_{2} \mathrm{~s}_{2} /$ ice $\mathrm{A1}^{+} / \mathrm{A2}^{+}$). Similar to this finding, in a study by Chiurillo et al, no congruency was detected between genotypes of $H$. pylori isolates and histological findings (19).

Besides variation in ethnicity of the participants, the observed diversity in genotypes could be explained through impaired DNA repair mechanisms during the replication that delivers several deletions and mutations (19). In our study, this diversity showed to have no impact on the transcription level of TNF-a in the infected patients compared with non-infected ones. Accordingly, overexpression of TNF- $a$ was detected just for patients infected with the strains belonged to genotype $A$ and $C$, which show no similarity in their genotypes. In general, a H. pylori strain with genotype A is considered virulent, where expression and secretion of CagA and VacA s $1 \mathrm{~m} 1$ in the gastric tissue is associated with the increased level of TNF- $a$ expression and inflammation (20). The induction of TNF- $a$ in three infected patients with cag $A$ negative strain carrying an inactive variant of $\operatorname{vacA~} \mathrm{s}_{2} \mathrm{~m}_{2}$ allele proposed the involvement of some other virulence factors, host factors, or microbes other than Helicobacter in this interplay. This discrepancy was previously reported by Zabaglia et al (21). Although carriage of iceA1/A2 allele in $H$. pylori isolates with genotype $\mathrm{C}$ could explain the induction of $T N F-a$ in the gastric tissue; lack of this induction in a patient infected with $H$. pylori genotype $E$ has challenged this link. Similar to our finding, in a study by Yamaoka et al. which was done on the gastric tissue, no significant difference in expression of TNF- $a$ was shown between the infected patients with $\operatorname{cag} A^{+}$and $\operatorname{cag} A^{-}$strains (22). A positive correlation between the expression of TNF-a gene with $/ L-8$ genes and Noxo1 genes in the H. pylori-positive group and with MMP-7, NoxO1, and ATP4A genes in the H. pylori-negative group confirms its role as a main inflammatory factor that acts as a master switch in establishing between inflammation and cancer (23).

Overexpression of IL-8, as the second important cytokine mediating a role in inflammation, as shown by these authors both in the corpus and antrum of infected patients with cag $A^{+}$genotype compared with $c a g A^{-}$ones. This finding is inconsistent with our results since the overexpression was just detected in the 
infected patients with genotype A. These results are in agreement with lqbal Siddique' (2014) and Celin Audibert' (2000) findings which showed that the presence of $\operatorname{cag} A$ is not associated with increased expression of $I L-8$ gene $(24,25)$. Regardless of defined genotypes, although 2.5 -fold higher level of IL-8 transcription was measured in $\mathrm{cagA}^{+}$compared with $\mathrm{cagA}^{-}$strains in our study, carriage of vacA s $1 \mathrm{~m} 1$ allele was a hallmark for explaining IL-8 overexpression in our samples since this allele was unique in the strains with genotype A, where nearly 8-fold higher level of the expression was detected compared with other genotypes.

One unanticipated finding was that the relative expression of the $I L-8$ gene was lower in the infected patients with $H$. pylori compared to non-infected patients. This result differs from some published studies (26-30), which suggested that $H$. pylori infection is not the only factor associated with IL-8 induction in the gastric tissue. Gene polymorphisms in the mediators of NF-KB pathway, induction of TGF- $\beta$, IL-10, and Muc-1, and interaction of non-Helicobacter bacteria are among other factors that can influence the expression of IL-8 in patients with gastritis (31). In the case of studied patients with H. pylori infection, these results suggested that there is a link between genotypes of $H$. pylori and the level of $I L-8$ gene expression. According to our knowledge, while no study examined the effect of complete H. pylori genotype on the extent of IL-8 transcription, similar to our results the higher level of IL-8 expression was previously established for $H$. pylori strains with $\operatorname{cag} A+/ \operatorname{vac} A \operatorname{sim} 1$ variant $(20,25,29)$.

MMP-7 is a member of the MMP family and a key player in the inflammation process and carcinogenesis, which increase in $H$. pylori gastritis and early gastric carcinoma $(32,33)$. Based on our results, a higher level of the MMP-7 mRNA was detected in the H. pylori-positive group than in the H. pylori-negative group, but this difference was not significant. These results match those observed in earlier studies (32-36). In the H. pylori-positive group, the patients infected with genotype $\mathrm{A}$ and $\mathrm{C}$ of $H$. pylori had higher expression of the MMP-7 gene compared to other genotypes and unlike previous studies, it was found that there was no relationship between the presence of cag $\mathrm{A}^{+} \mathrm{H}$. pylori strains and the increase in $M M P-7$ gene in patients $(36,37)$. The ice $A 1$ and ice A1/A2 seem to be involved in MMP-7 expression that is suggested due to the presence of inactive vacA allele and cagPAl in the stains with genotype $C$. However, lack of MMP-7 induction in a sample with H.pylori genotype $\mathrm{E}$, which carry this virulence gene, again showed the complexity for the description of this correlation.

$\mathrm{H}+, \mathrm{K}+$-adenosine triphosphatase $(\mathrm{H}+, \mathrm{K}+-\mathrm{ATPase})$ as a proton pump and a marker of parietal cell function is the key pathway mediating the secretion of gastric acid and is affected by H. pylori. H. pylori or its products inhibit the activity of the promoter of the alpha-subunit of $\mathrm{H}+\mathrm{K}+\mathrm{ATPase}$ and suppress the expression of $\mathrm{H}+, \mathrm{K}+-\mathrm{ATPase}(38,39)$. A few studies have examined the changes in the expression level of the ATP4A gene in human gastric. Our results are almost in line with Nayoung Kim and Ok Jae Lee's (2020) findings which showed there were no significant differences in ATP4A mRNA level between $H$. pylori-negative and H. pylori-positive groups (38). In our study, downregulation of ATP4A was detected for all genotypes, except genotypes $B$ and $E$, where overexpression was detected in only one patient. This finding showed that transcription of this gene could be mediated by different pathways, independent of genotypes of $H$. pylori strains. In previous studies, the effect of existence cagA and type IV secretory 
system (T4SS), cagL, for repression of ATP4A expression was confirmed in studies of H. pylori cagPAI strains (40-42), but in our study, such a relationship was not seen.

NADPH oxidase organizer 1 (NOXO 1) is one of the components forming the NOX1 complex. It is known as a TNF-a-dependent tumor-promoting factor for gastric inflammation (43). Several reports have shown that Noxo1 expression is significantly upregulated in gastritis as well as the intestinal-type or diffuse-type gastric cancer $(43,44)$. In our study, there was no difference in the relative expression of the Noxo1 gene between the two groups of patients. This result may be explained by the fact that all the samples used in our study were from the gastric tissue of patients with chronic gastritis. In the H. pylori-positive group, the patients infected with genotypes $\mathrm{B}$ and $\mathrm{C}$ showed higher levels of Noxo1 expression compared with the other genotypes; however, no virulence factor could describe this increased level of the expression. Alteration in the expression level of Noxo1 accompany with TNF- $a$ and IL-8 in the H. pylori-positive group and its link with TNF-a in the H. pylori-negative group represents its role in gastritis irrespective of the type of infections in the gastric tissue. In future studies, determining the role of infection with other microbes could shed light on this interaction.

\section{Conclusion}

In general, in this study, we investigated the impact of $H$. pylori infection and its characterized combined virulence genotypes on transcriptional changes of genes linked to the inflammatory pathway in the gastric tissue of the infected compared with non-infected patients with chronic gastritis. Our results showed complexity in the transcription of genes link to the inflammatory pathways in the gastric tissue respective to the characterized $H$. pylori genotypes. A direct relationship with overexpression of $I L-8, T N F-$ $a$, and MMP-7 genes and downregulation of Noxo-1 and ATP4A was detected in the samples of patients infected with hypervirulent strains with genotype A compared with other genotypes. Irrespective of genotypes of $H$. pylori, our results showed a significant positive correlation between transcriptional changes of IL8 in conjunction with Noxo1 and/or TNF- $a$ in H. pylori-infected patients that was different from the characterized correlation in the transcription of TNF- $a$ and ATP4A/Noxo1/MMP-7 genes in $\mathrm{H}$. pylori-negative patients with gastritis. This finding proposed the involvement of some other host factors, such as gene polymorphisms in the mediators of the NF-kB pathway, the interplay of the antiinflammatory pathway, and the interaction of non-Helicobacter bacteria in this regard. More studies on a larger number of samples, especially those with characterized microbiota and related host immunogenetics and transcriptional data could provide valuable documents about this interaction.

\section{Declarations}

\section{Acknowledgments}

The authors would like to thank all colleagues of Pediatric Infections Research Center (PIRC), Research Institute for Children's Health, Mofid Children's Hospital, Shahid Beheshti University of Medical Sciences, Tehran, Iran for their cooperation in this study. The authors of this study also thank the kindly support of 
gastroenterology and pathology units of Firoozgar hospital, Iran university of medical sciences, Tehran, Iran.

\section{Author contributions}

We declare that all the authors fulfilled the authorship criteria and All authors read and approved the final version of the manuscript.

\section{Funding}

This study was funded by a Ph.D. grant from the Department of Pathobiology, School of Public Health, Tehran University of Medical Sciences, Tehran, Iran.

\section{Declarations}

\section{Conflict of interest}

The authors declare that there is no conflict of interest.

\section{Ethical approval}

This study was approved by the ethical committee of the Research Center in Tehran University of Medical Science (accepted Number, IR.TUMS.SPH.REC.1398.167 1398/7/3) and an informed consent form was obtained from all the patients.

\section{Informed consent}

The authors included in the study consent to this manuscript to participate and for publication.

\section{Consent for publication}

The authors declare that they consent for publication of this study.

\section{References}

1. Varbanova M, Frauenschläger K, Malfertheiner PJBP, Gastroenterology RC. Chronic gastritis-An update. 2014;28(6):1031-42.

2. Qadri Q, Rasool R, Gulzar G, Naqash S, Shah ZAJJogc. H. pylori infection, inflammation and gastric cancer. 2014;45(2):126-32.

3. Carrasco G, Corvalan AHJGr, practice. Helicobacter pylori-induced chronic gastritis and assessing risks for gastric cancer. 2013;2013.

4. Ricci V, Romano M, Boquet PJWjogW. Molecular cross-talk between Helicobacter pylori and human gastric mucosa. 2011;17(11):1383. 
5. Riggio MP, Lennon A, Wray DJJoop, medicine. Detection of Helicobacter pylori DNA in recurrent aphthous stomatitis tissue by PCR. 2000;29(10):507-13.

6. Jia E-Z, Zhao F-J, Hao B, Zhu T-B, Wang L-S, Chen B, et al. Helicobacter pylori infection is associated with decreased serum levels of high density lipoprotein, but not with the severity of coronary atherosclerosis. 2009;8(1):1-7.

7. Farsak B, Yildirir A, Akyön Y, Pinar A, Öç M, Böke E, et al. Detection of Chlamydia pneumoniae andHelicobacter pylori DNA in Human Atherosclerotic Plaques by PCR. 2000;38(12):4408-11.

8. Correa P, Piazuelo MBJJodd. The gastric precancerous cascade. 2012;13(1):2-9.

9. Isomoto H, Mizuta Y, Miyazaki M, Takeshima F, Omagari K, Murase K, et al. Implication of NF-KB in Helicobacter pylori-associated gastritis. 2000;95(10):2768-76.

10. Liu T, Zhang L, Joo D, Sun S-CJSt, therapy t. NF-KB signaling in inflammation. 2017;2(1):1-9.

11. Williams RA, Timmis J, Qwarnstrom EEJC. Computational models of the NF-KB signalling pathway. 2014;2(4):131-58.

12. Hammond CE, Beeson C, Suarez G, Peek Jr RM, Backert S, Smolka AJJAJoP-G, et al. Helicobacter pylori virulence factors affecting gastric proton pump expression and acid secretion. 2015;309(3):G193-G201.

13. Yadegar A, Mobarez AM, Alebouyeh M, Mirzaei T, Kwok T, Zali MRJWJoM, et al. Clinical relevance of cagL gene and virulence genotypes with disease outcomes in a Helicobacter pylori infected population from Iran. 2014;30(9):2481-90.

14. Saberi S, Douraghi M, Azadmanesh K, Shokrgozar MA, Zeraati H, Hosseini ME, et al. A potential association between Helicobacter pylori CagA EPIYA and multimerization motifs with cytokeratin 18 cleavage rate during early apoptosis. 2012;17(5):350-7.

15. Vaziri F, Peerayeh SN, Alebouyeh M, Mirzaei T, Yamaoka Y, Molaei M, et al. Diversity of Helicobacter pylori genotypes in Iranian patients with different gastroduodenal disorders. 2013;19(34):5685.

16. Ta LH, Hansen LM, Sause WE, Shiva O, Millstein A, Ottemann KM, et al. Conserved transcriptional unit organization of the cag pathogenicity island among Helicobacter pylori strains. 2012;2:46.

17. Wisnieski F, Calcagno DQ, Leal MF, dos Santos LC, de Oliveira Gigek C, Chen ES, et al. Reference genes for quantitative RT-PCR data in gastric tissues and cell lines. 2013;19(41):7121.

18. Festuccia C, Gravina GL, Giorgio C, Mancini A, Pellegrini C, Colapietro A, et al. UniPR1331, a small molecule targeting Eph/ephrin interaction, prolongs survival in glioblastoma and potentiates the effect of antiangiogenic therapy in mice. 2018;9(36):24347.

19. Chiurillo MA, Moran Y, Cañas M, Valderrama E, Granda N, Sayegh M, et al. Genotyping of Helicobacter pylori virulence-associated genes shows high diversity of strains infecting patients in western Venezuela. 2013;17(9):e750-e6.

20. Augusto AC, Miguel F, Mendonça S, Pedrazzoli Jr J, Gurgueira SAJCb. Oxidative stress expression status associated to Helicobacter pylori virulence in gastric diseases. 2007;40(9-10):615-22. 
21. Zabaglia LM, Ferraz MA, Pereira WN, Orcini WA, de Labio RW, Neto AC, et al. Lack of association among TNF-a gene expression,-308 polymorphism ( $\mathrm{G}>\mathrm{A})$ and virulence markers of Helicobacter pylori. 2015;21(1):1-7.

22. Yamaoka Y, Kita M, Kodama T, Sawai N, Imanishi JJG. Helicobacter pylori cagA gene and expression of cytokine messenger RNA in gastric mucosa. 1996;110(6):1744-52.

23. Wu Y-d, Zhou BJBjoc. TNF-a/NF-k B/Snail pathway in cancer cell migration and invasion. 2010;102(4):639-44.

24. Siddique I, Al-Qabandi A, Al-Ali J, Alazmi W, Memon A, Mustafa AS, et al. Association between Helicobacter pylori genotypes and severity of chronic gastritis, peptic ulcer disease and gastric mucosal interleukin-8 levels: Evidence from a study in the Middle East. 2014;6(1):1-10.

25. Audibert C, Janvier B, Grignon B, Salaüna L, Burucoa C, Lecron J-C, et al. Correlation between IL-8 induction, cagA status and vacA genotypes in 153 French Helicobacter pylori isolates. 2000;151(3):191-200.

26. Crabtree J, Wyatt J, Trejdosiewicz L, Peichl P, Nichols P, Ramsay N, et al. Interleukin-8 expression in Helicobacter pylori infected, normal, and neoplastic gastroduodenal mucosa. 1994;47(1):61-6.

27. Moss S, Legon S, Davies J, Calam JJG. Cytokine gene expression in Helicobacter pylori associated antral gastritis. 1994;35(11):1567-70.

28. Sharma SA, Tummuru MK, Blaser MJ, Kerr LDJTjoi. Activation of IL-8 gene expression by Helicobacter pylori is regulated by transcription factor nuclear factor-kB in gastric epithelial cells. 1998;160(5):2401-7.

29. Bartchewsky Jr W, Martini MR, Masiero M, Squassoni AC, Alvarez MC, Ladeira MS, et al. Effect of Helicobacter pylori infection on IL-8, IL-1 $\beta$ and COX-2 expression in patients with chronic gastritis and gastric cancer. 2009;44(2):153-61.

30. Outlioua A, Badre W, Desterke C, Echarki Z, El Hammani N, Rabhi M, et al. Gastric IL-1 $\beta$, IL-8, and IL17A expression in Moroccan patients infected with Helicobacter pylori may be a predictive signature of severe pathological stages. 2020;126:154893.

31. Bornschein J, Kandulski A, Selgrad M, Malfertheiner PJDD. From gastric inflammation to gastric cancer. 2010;28(4-5):609-14.

32. Lu L, Ma G, Liu X, Sun R, Wang Q, Liu M, et al. Correlation between GDF15, MMP7 and gastric cancer and its prognosis. 2017;21(3):535-41.

33. Gontar Siregar SH, Sitepu RJOaMjoms. Serum IL-10, MMP-7, MMP-9 levels in Helicobacter pylori infection and correlation with degree of gastritis. 2016;4(3):359.

34. Lu P, Takai K, Weaver VM, Werb ZJCSHpib. Extracellular matrix degradation and remodeling in development and disease. 2011;3(12):a005058.

35. Wroblewski LE, Noble P-J, Pagliocca A, Pritchard DM, Hart CA, Campbell F, et al. Stimulation of MMP7 (matrilysin) by Helicobacter pylori in human gastric epithelial cells: role in epithelial cell migration. 2003;116(14):3017-26. 
36. Sadeghiani M, Bagheri N, Shahi H, Reiisi S, Rahimian G, Rashidi R, et al. cag Pathogenicity islanddependent upregulation of matrix metalloproteinase-7 in infected patients with Helicobacter pylori. 2017;38(6):595-607.

37. Crawford HC, Krishna US, Israel DA, Matrisian LM, Washington MK, Peek Jr RMJG. Helicobacter pylori strain-selective induction of matrix metalloproteinase-7 in vitro and within gastric mucosa. 2003;125(4):1125-36.

38. Kim HJ, Kim N, Park JH, Choi S, Shin CM, Lee OJJG, et al. Helicobacter pylori eradication induced constant decrease in interleukin-1B expression over more than 5 years in patients with gastric cancer and dysplasia. 2020;14(6):735.

39. Yao X, Smolka AJJG. Gastric parietal cell physiology and Helicobacter pylori-induced disease. 2019;156(8):2158-73.

40. Saha A, Backert S, Hammond CE, Gooz M, Smolka AJJG. Helicobacter pylori CagL activates ADAM17 to induce repression of the gastric H, K-ATPase a subunit. 2010;139(1):239-48.

41. Chang W-L, Yeh Y-C, Sheu B-SJJobs. The impacts of $H$. pylori virulence factors on the development of gastroduodenal diseases. 2018;25(1):1-9.

42. Saha A, Hammond CE, Trojanowska M, Smolka AJJAJoP-G, Physiology L. Helicobacter pyloriinduced $\mathrm{H}, \mathrm{K}$-ATPase a-subunit gene repression is mediated by NF-KB p50 homodimer promoter binding. 2008;294(3):G795-G807.

43. Oshima H, Ishikawa T, Yoshida G, Naoi K, Maeda Y, Naka K, et al. TNF-a/TNFR1 signaling promotes gastric tumorigenesis through induction of Noxo1 and Gna14 in tumor cells. 2014;33(29):3820-9.

44. Echizen K, Horiuchi K, Aoki Y, Yamada Y, Minamoto T, Oshima H, et al. NF-KB-induced NOX1 activation promotes gastric tumorigenesis through the expansion of SOX2-positive epithelial cells. 2019;38(22):4250-63.

45. Lou X, Zhu H, Ning L, Li C, Li S, Du H, et al. EZH2 regulates intestinal inflammation and necroptosis through the JNK signaling pathway in intestinal epithelial cells. 2019;64(12):3518-27.

46. Ohki R, Yamamoto K, Mano H, Lee RT, Ikeda U, Shimada KJJoh. Identification of mechanically induced genes in human monocytic cells by DNA microarrays. 2002;20(4):685-91.

47. Binato R, Santos EC, Boroni M, Demachki S, Assumpção P, Abdelhay EJO. A common molecular signature of intestinal-type gastric carcinoma indicates processes related to gastric carcinogenesis. 2018;9(7):7359.

48. Rubach M, Lang R, Hofmann T, Somoza VJAotNYAoS. Time-dependent component-specific regulation of gastric acid secretion-related proteins by roasted coffee constituents. 2008;1126(1):310-4.

49. Vandesompele J, De Preter K, Pattyn F, Poppe B, Van Roy N, De Paepe A, et al. Accurate normalization of real-time quantitative RT-PCR data by geometric averaging of multiple internal control genes. 2002;3(7):1-12.

50. Steinau M, Rajeevan MS, Unger ERJTJoMD. DNA and RNA references for qRT-PCR assays in exfoliated cervical cells. 2006;8(1):113-8. 


\section{Tables}

Table 1 Primer sequences for the RT-PCR analysis

\begin{tabular}{|c|c|c|c|c|c|}
\hline \multirow[t]{2}{*}{ Name } & Sequence & \multirow{2}{*}{$\begin{array}{l}\text { Length } \\
\text { (bp) }\end{array}$} & \multirow{2}{*}{$\begin{array}{c}\text { Size of } \\
\text { Product } \\
\text { (bp) }\end{array}$} & \multirow{2}{*}{$\begin{array}{c}\text { Annealing } \\
\text { tm }\end{array}$} & \multirow[t]{2}{*}{ References } \\
\hline & $\left(5^{\prime}\right.$ & & & & \\
\hline \multirow[t]{2}{*}{$T N F-\alpha^{1}$} & F: GAGGCCAAGCCCTGGTATG & 19 & \multirow[t]{2}{*}{91} & \multirow[t]{2}{*}{60} & \multirow[t]{2}{*}{$(45)$} \\
\hline & R: CGGGCCGATTGATCTCAGC & 19 & & & \\
\hline \multirow[t]{2}{*}{$I L-82^{2}$} & $\begin{array}{l}\text { F: } \\
\text { GAACTGAGAGTGATTGAGAGTGGA }\end{array}$ & 24 & \multirow[t]{2}{*}{134} & \multirow[t]{2}{*}{62} & \multirow[t]{2}{*}{$(46)$} \\
\hline & $\begin{array}{l}\text { R: } \\
\text { CTCTTCAAAAACTTCTCCACAACC } \\
\end{array}$ & 24 & & & \\
\hline \multirow[t]{2}{*}{ Noxo1 ${ }^{3}$} & F: AGATCAAGAGGCTCCAAACG & 20 & \multirow[t]{2}{*}{120} & \multirow[t]{2}{*}{60} & \multirow[t]{2}{*}{$(44)$} \\
\hline & R: GGAAGGTCTCCTTGAGGGTCT & 21 & & & \\
\hline \multirow[t]{2}{*}{$M M P-7^{4}$} & $\begin{array}{l}\text { F: } \\
\text { TGCAGAAGCCCAGATGTGGAGTG }\end{array}$ & 23 & \multirow[t]{2}{*}{96} & \multirow[t]{2}{*}{62} & \multirow[t]{2}{*}{$(47)$} \\
\hline & $\begin{array}{l}\text { R: } \\
\text { CGATCCTGTAGGTGACCACTTTGG }\end{array}$ & 24 & & & \\
\hline \multirow[t]{2}{*}{$A T P 4 A^{5}$} & F: CGGCCAGGAGTGGACATTCG & 20 & \multirow[t]{2}{*}{176} & \multirow[t]{2}{*}{60} & \multirow[t]{2}{*}{$(48)$} \\
\hline & R: ACACGATGGCGATCACCAGG & 20 & & & \\
\hline \multirow[t]{2}{*}{$\beta 2 M^{6}$} & $\begin{array}{l}\text { F: } \\
\text { TGCTGTCTCCATGTTTGATGTATCT }\end{array}$ & 25 & \multirow[t]{2}{*}{86} & \multirow[t]{2}{*}{60} & \multirow[t]{2}{*}{$(49)$} \\
\hline & R: TCTCTGCTCCССАCСТCTAAGT & 22 & & & \\
\hline \multirow[t]{2}{*}{$\beta$-actin ${ }^{7}$} & F: ATGTGGCCGAGGACTTTGATT & 21 & \multirow[t]{2}{*}{107} & \multirow[t]{2}{*}{60} & \multirow[t]{2}{*}{$(50)$} \\
\hline & R: AGTGGGGTGGCTTTTAGGATG & 21 & & & \\
\hline
\end{tabular}

1. Tumor necrosis factor-alpha

2. Interleukin (IL)-8

3. Nicotinamide dinucleotide phosphate (NADPH) oxidase 1

4. Matrix metallopeptidase 7

5. ATPase $\mathrm{H}+/ \mathrm{K}+$ Transporting Subunit Alpha

6. Beta-2 microglobulin

7. Beta-actin

Table 2 Relative expression (Mean \pm SD) of genes in two groups of patients, moderate chronic gastritis/ H. pylori positive and moderate chronic gastritis/ $H$. pylori negative. ${ }^{1}$ 


\begin{tabular}{|c|c|c|c|c|c|}
\hline \multirow[t]{2}{*}{ Groups } & $I L-8$ & TNF- $\alpha$ & MMP-7 & NOXO1 & ATP4A \\
\hline & $\begin{array}{c}\text { Relative } \\
\text { expression } \\
\text { Mean } \pm \text { SD }\end{array}$ & $\begin{array}{c}\text { Relative } \\
\text { expression } \\
\text { Mean } \pm S D\end{array}$ & $\begin{array}{c}\text { Relative } \\
\text { expression } \\
\text { Mean } \pm S D\end{array}$ & $\begin{array}{c}\text { Relative } \\
\text { expression } \\
\text { Mean } \pm \text { SD }\end{array}$ & $\begin{array}{c}\text { Relative } \\
\text { expression } \\
\text { Mean } \pm \text { SD }\end{array}$ \\
\hline $\begin{array}{c}\text { derate chronic gastritis/ } \\
\text { H. pylori positive }\end{array}$ & $\begin{array}{c}1.203 \\
\pm \\
2.805\end{array}$ & $\begin{array}{c}2.084 \\
\pm \\
2.684\end{array}$ & $\begin{array}{c}3.242 \\
\pm \\
3.727\end{array}$ & $\begin{array}{c}3.641 \\
\pm \\
4.805\end{array}$ & $\begin{array}{c}4.299 \\
\pm \\
9.051\end{array}$ \\
\hline $\begin{array}{l}\text { derate chronic gastritis/ } \\
\text { H. pylori negative }\end{array}$ & $\begin{array}{c}2.587 \\
\pm \\
2.28\end{array}$ & $\begin{array}{c}1.342 \\
\pm \\
1.068\end{array}$ & $\begin{array}{c}1.939 \\
\pm \\
1.398\end{array}$ & $\begin{array}{c}3.645 \\
\pm \\
8.613\end{array}$ & $\begin{array}{c}2.779 \\
\pm \\
3.962\end{array}$ \\
\hline
\end{tabular}

ve gene expressions for all samples were determined from the obtained Ct (Crossing hold) values and using the $2^{-\Delta \Delta c t}\left(2^{\wedge}\right.$ - (Sample $\Delta$ ct- Average control group $\left.\Delta c t\right)$ method. Up- and regulation was defined based on $\mathrm{RQ}$ values $\geq 2$ and $\leq 0.5$, respectively.

\section{Figures}
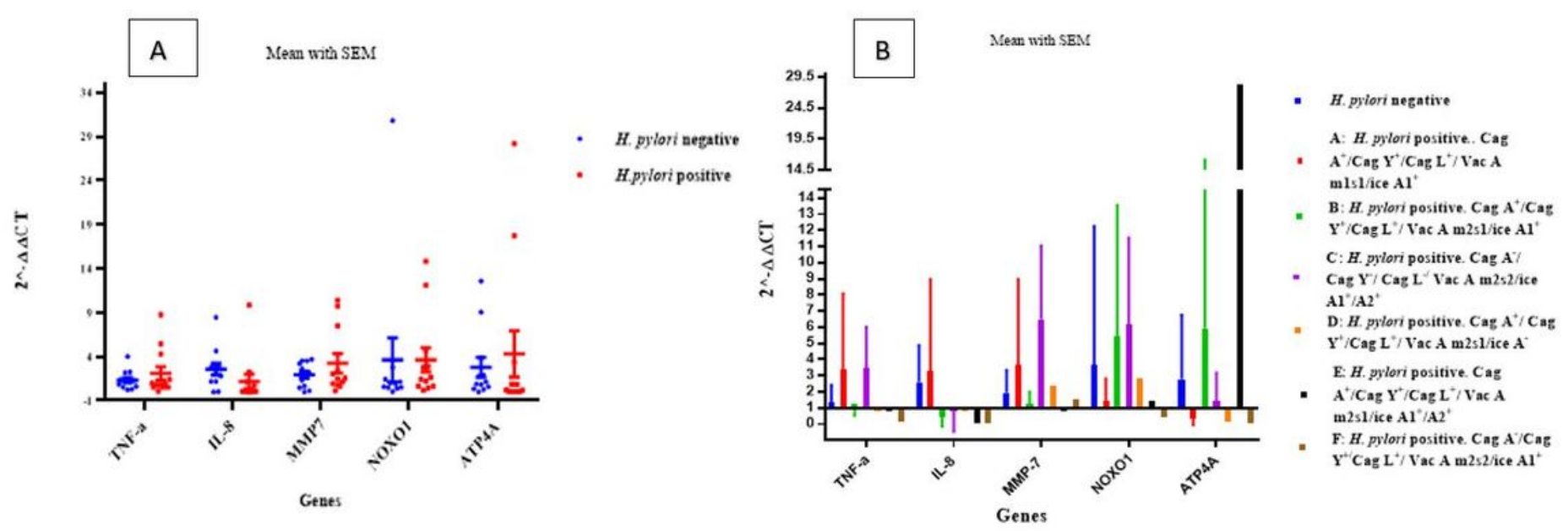

Figure 1

A comparison of genes expression between the two groups of patients in all samples (moderate chronic gastritis/ Helicobacter pylori (H. pylori) positive, moderate chronic gastritis/ H. pylori negative), B Comparison between $\mathrm{H}$. pylori genotypes and relative expression values of genes

\section{Supplementary Files}

This is a list of supplementary files associated with this preprint. Click to download. 
- supplementary.docx 